\title{
Toward an Integrated Model for Raised-Bog Development: Theory and Field Evidence
}

\section{Citation}

Almquist-Jacobson, H., and D. R. Foster. 1995. Toward an Integrated Model for RaisedBog Development: Theory and Field Evidence. Ecology 76, no. 8: 2503-2516. Portico. doi: $10.2307 / 2265824$.

\section{Published Version}

doi: $10.2307 / 2265824$

\section{Permanent link}

http://nrs.harvard.edu/urn-3:HUL.InstRepos:29395005

\section{Terms of Use}

This article was downloaded from Harvard University's DASH repository, and is made available under the terms and conditions applicable to Other Posted Material, as set forth at http:// nrs.harvard.edu/urn-3:HUL.InstRepos:dash.current.terms-of-use\#LAA

\section{Share Your Story}

The Harvard community has made this article openly available.

Please share how this access benefits you. Submit a story.

\section{Accessibility}




\title{
TOWARD AN INTEGRATED MODEL FOR RAISED-BOG DEVELOPMENT: THEORY AND FIELD EVIDENCE ${ }^{1}$
}

\author{
H. Almquist-Jacobson ${ }^{2}$ \\ Department of Quaternary Geology, Lund University, S223-63 Lund, Sweden \\ D. R. Foster \\ Harvard Forest, Harvard University, Petersham, Massachusetts 01366 USA
}

\begin{abstract}
The development and distribution of Northern mires, including minerotrophic fens and ombrotrophic raised bogs, frequently are presumed to be strongly controlled by the interplay of regional climate and site geomorphology and history. Investigations of these relationships provide insights into long-term trends in ecosystem development by linking geological and landscape-scale processes. In this study, a theoretical model for raised-bog development integrates internal bog hydrodynamics with external factors, including local substrate characteristics, and regional temperature and moisture conditions. The model is used to interpret the development of raised bogs in the Bergslagen region, which coincides with the modern northern distributional limit of those mires in central Sweden. The development of minerotrophic fens that precede bog formation is also considered. Basal radiocarbon dates along surveyed transects are used to assess the pattern and timing of peatland formation and rates of lateral expansion. Previous palynological and lake-level studies from the same region provide independent evidence for changes in Holocene climate.

Fen initiation in the region occurred throughout the Holocene under a broad range of environmental conditions. Once established, fens appear to expand faster during moister periods. Locally, substrate slope is an important mediator of fen development, with slopes $>0.5 \%$ inhibiting lateral expansion. Accumulation of Sphagnum peat, an indicator of raisedbog initiation, occurred from $\approx 4000$ to $5000 \mathrm{yr}$ BP during relatively dry phases. Rates of lateral expansion were not significantly affected by increasing moisture or by decreasing temperatures until at least $2000 \mathrm{yr}$ BP. However, modern geographic trends in cross-sectional shape of mires suggest that, at the northern limit of their range today, raised bogs are limited by low temperatures.
\end{abstract}

Key words: climate; ecosystems; Holocene; hydrology; peatlands; topography.

\section{INTRODUCTION}

\section{Background}

Assessing ecosystem responses to climate change requires understanding not only modern climate-ecosystem relationships, but also the developmental processes inherent in those ecosystems and their sensitivity and response to past changes in climate. Geographic trends in mire types indicate that climate influences the development and differentiation of peatlands. Across boreal and subboreal regions the zonation of raised bogs and minerotrophic fens corresponds to isopleths of temperature and precipitation (Granlund 1932, Eurola and Vorren 1980). Among raised bogs in particular, geographic gradients in bog height and shape, surficial landforms, and gross stratigraphy across Scandinavia (Granlund 1932) and eastern North America (Damman 1977, Glaser and Janssens 1986) have been attributed primarily to moisture regime. These geographic trends

\footnotetext{
${ }^{1}$ Manuscript received 26 September 1994; revised 6 March 1995; accepted 30 March 1995.

${ }^{2}$ Present address: Departments of Plant Biology and Geological Sciences, and Institute for Quaternary Studies, University of Maine, Orono, Maine 04469-5726 USA.
}

and the reliance of raised bogs on atmospheric inputs for moisture and nutrients have led researchers to interpret peat stratigraphy from bogs as sensitive records of past climate. Consequently, stratigraphic changes in peat composition, humification, and rates of vertical accretion have been interpreted climatically for over a century (Blytt 1876, Godwin 1952, Barber 1981; see Frenzel 1983).

However, in recent decades scientists have debated the degree to which raised bogs respond to allogenic (external) influences such as climate and local hydrology, as opposed to autogenic processes associated with their own composition or hydrology. Theoretical models describing hydrology and growth of raised bogs (Clymo 1978, 1984, Ivanov 1981, Ingram 1982, Winston 1994) have suggested that autogenic mechanisms are responsible for some changes in vertical accretion, lateral expansion, and consequent shape of these peatlands. As a result, studies in which raised-bog development is interpreted solely in terms of climatic change have been replaced by others in which field evidence is used to test developmental models (Foster and Wright 1990, Korhola 1992, Warner et al. 1993). Globally, boreal mires represent an important sink for car- 


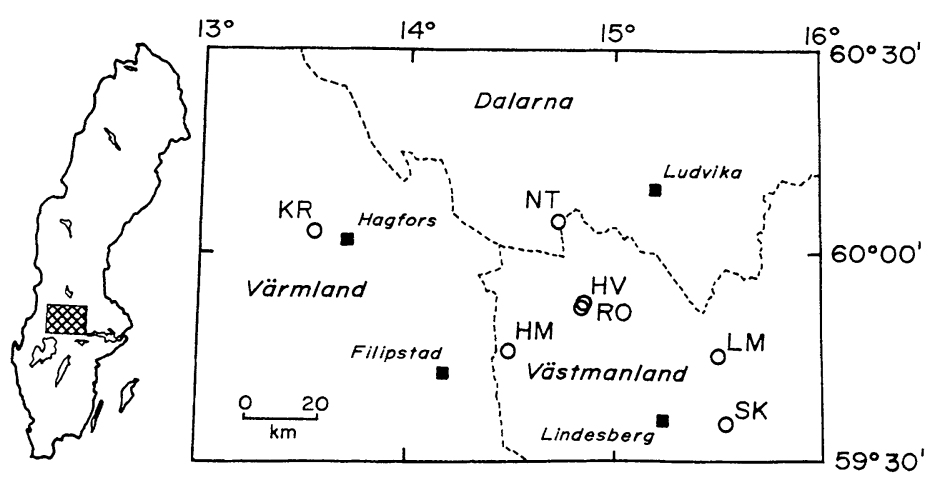

FIG. 1. Location of the study sites within Sweden: Hammarmossen (HM), Nittenmossen (NT), Kärrmossen (KR), Stora Kroksmossen (SK), Norra Römyren (RO), Limbergsmossen (LM), and Havsjömossen (HV).

bon (see Malmer 1992). However, at a particular time they may act as either a source or a sink of carbon, depending on their developmental stage and prevailing climatic conditions (Warner et al. 1993).

Teasing apart allogenic and autogenic influences on ecosystem development can be approached by paleoecological and paleogeographical studies. Here we consider an integrated model of mire development, together with independent evidence of Holocene climate inferred from pollen and lake-level studies, to infer the processes affecting the initiation and development of seven raised bogs within a $6500 \mathrm{~km}^{2}$ area of central Sweden (Fig. 1; Table 1). Specifically, we evaluate spatial and temporal patterns in (1) mire initiation, (2) conversion of fen to bog, (3) fen and bog expansion, and (4) modern bog geometry.

\section{The integrated model}

Raised bogs are domed mires that can be up to 10 $m$ in height, and often circular or elliptic in plan view. The peat mass consists predominantly of partially decomposed Sphagnum mosses that function in two layers, the uppermost "acrotelm," which includes a few decimetres of undecomposed to slightly decomposed peat lying above the drought stage of the bog's water table, and the lower "catotelm," which includes permanently saturated peat (Clymo 1984). Although water-saturated almost to the surface, these ombrotrophic mires receive virtually all water and nutrients from the atmosphere. In some cases the base of the mire lies several metres above the local groundwater aquifer ( $\mathrm{J}$. E. Almendinger et al., unpublished data). Many bogs have concentric or eccentric patterns of surficial features, including hummocks and hollows or arcuate pools along the elevational contours.

The "integrated model" of raised-bog development presented here combines theories of (1) bog hydrology (Ivanov 1981, Ingram 1982), (2) peat growth (Clymo $1978,1984)$, and (3) the differentiation of surface features resulting from hydrology and patterns of peat accumulation (Foster and Wright 1990). Part of the model involves equations that describe hydrological and biological constraints on the growth and geometry of an idealized concentric raised bog initiating from a single locus and expanding across (paludifying) an unobstructed horizontal impermeable plane under steady-state conditions. However, in its entirety, the model does not assume that bogs initiate from a single locus or that they are unaffected by allogenic factors. Rather, it describes conceptually the hydrodynamic consequences of bog coalescence and hydrologic mechanisms through which climate and local hydrogeology together influence bog development and geometry. Although fen development is also examined in this paper, the integrated model, itself, applies only to the raised bogs that succeed the fen phase.

Mathematical relationships.-In the most basic sense, concentric raised bogs behave (in cross section) as hemi-elliptical groundwater mounds with vertical equipotentials, as described by the equation,

$$
\frac{U}{k}=\frac{2 H^{2}}{R^{2}-r^{2}}
$$

where $U=$ recharge percolating down to the water

TABLE 1. Locations of the study sites.

\begin{tabular}{|c|c|c|c|c|}
\hline Site & Latitude & Longitude & Province & $\begin{array}{c}\text { Altitude } \\
\text { (m a.s.l.)* }\end{array}$ \\
\hline Nittenmossen & $60^{\circ} 05^{\prime} 00^{\prime \prime} \mathrm{N}$ & $14^{\circ} 31^{\prime} 00^{\prime \prime} \mathrm{E}$ & Dalarna & 285 \\
\hline Kärrmossen & $60^{\circ} 03^{\prime} 15^{\prime \prime} \mathrm{N}$ & $13^{\circ} 32^{\prime} 20^{\prime \prime} \mathrm{E}$ & Värmland & 150 \\
\hline Havsjömossen & $59^{\circ} 52^{\prime} 20^{\prime \prime} \mathrm{N}$ & $14^{\circ} 50^{\prime} 40^{\prime \prime} \mathrm{E}$ & Västmanland & 170 \\
\hline Norra Römyren & $59^{\circ} 51^{\prime} 30^{\prime \prime} \mathrm{N}$ & $14^{\circ} 50^{\prime} 10^{\prime \prime} \mathrm{E}$ & Västmanland & 170 \\
\hline Hammarmossen & $59^{\circ} 45^{\prime} 40^{\prime \prime} \mathrm{N}$ & $14^{\circ} 29^{\prime} 30^{\prime \prime} \mathrm{E}$ & Västmanland & 185 \\
\hline Limbergsmossen & $59^{\circ} 45^{\prime} 25^{\prime \prime} \mathrm{N}$ & $15^{\circ} 30^{\prime} 20^{\prime \prime} \mathrm{E}$ & Västmanland & 130 \\
\hline Stora Kroksmossen & $59^{\circ} 35^{\prime} 30^{\prime \prime} \mathrm{N}$ & $15^{\circ} 31^{\prime} 30^{\prime \prime} \mathrm{E}$ & Västmanland & 75 \\
\hline
\end{tabular}

\footnotetext{
*a.s.l. = above sea level.
} 
table, $k=$ horizontal permeability (or hydraulic conductivity) of the peat, $R=$ bog radius, and $H=$ mound height at distance $r$ from the bog center (see Ingram 1982).

The maximum height that a bog can attain $\left(H_{\max }\right)$ is determined by a dynamic equilibrium between the rate at which organic matter is added to the catotelm $\left(\rho_{c}\right)$ and the cumulative decomposition (and compaction) within the catotelm $\left(\alpha_{c}\right)$ (rather than by hydrologic variables), so that

$$
H_{\max }=\frac{\rho_{c}}{\alpha_{c}}
$$

(Clymo 1984).

In a concentric raised bog, the maximum height occurs at the mire center where $R=r$ and thus

$$
H_{\max }=\left(\frac{U R^{2}}{2 k}\right)^{1 / 2}
$$

(Ivanov 1981, Ingram 1982). Eqs. 2 and 3 can be combined to show that the radius $(R)$ of a bog at maximum height $\left(H_{\max }\right)$ is constrained by the bog's own hydraulic characteristics such that

$$
R=\frac{\rho_{c}}{\alpha_{c}}\left(\frac{2 k}{U}\right)^{1 / 2} .
$$

Bog initiation.-Bogs initiate from either a single locus followed by concentric expansion of the mire or from several loci that eventually coalesce (Foster and Wright 1990, Korhola 1992). Eq. 1 describes a peat mass formed from a single locus. When two such masses coalesce, the newly formed composite bog presumably would not conform to Eq. 1 for some time.

"Vertical-growth" phase.-The model suggests that during the initial phase of bog development, and in the absence of topographic barriers, lateral expansion is strongly controlled by net vertical peat accumulation. Under stable climatic conditions, which would hold $U$ and $\rho_{c}$ constant, $\alpha_{c}$ would gradually increase as the catotelm thickened; net vertical peat accumulation and lateral expansion would gradually decrease until the maximum equilibrium height is approached. As organic inputs and decay continue with diminishing net increase in bog height, the age/depth curve of the peat profile becomes increasingly curvilinear and eventually asymptotic (Clymo 1984). Curvilinear age/depth curves have been demonstrated on several sites (Aaby and Tauber 1974, Clymo 1984, Foster and Wright 1990, Warner et al. 1993), which suggests that the conditions of the model can indeed be achieved in nature. During the vertical-growth phase, the rate of lateral expansion would depend on the rate of vertical accumulation so long as bog height and width remain in equilibrium, a condition that must be determined by field evidence. At the same time, climate can affect the rate of bog expansion and ultimately $H_{\max }$ by influencing $\rho_{c}$ and $\alpha_{c}$.

"Expanding-plateau" phase.-Eq. 4 implies that, under constant climate conditions, bogs may continue to expand laterally after the maximum equilibrium bog height is reached because of increasing horizontal permeability $(k)$ relative to vertical permeability. Increasing anisotropy of the peat mass would naturally occur with compaction of decay-resistant material in the catotelm. If a bog continues to expand laterally after $H_{\max }$ has been reached, the bog expanse flattens and reduced run-off from the mire surface may induce formation of surficial pools. As the central plateau expands concentrically, additional pools form continually on the newly flattened areas, creating a concentric pattern of pools with a predictable age distribution (Foster and Wright 1990).

Influence of site topography.-Raised bogs on sloping substrates are typically elongated downslope, presumably because the delivery of excess water to the downslope end of the mire enhances conditions for peat formation there. Expansion is often most rapid downslope (Foster et al. 1988, Korhola 1992). If the mire margin encounters a topographic barrier, $R$ would be held constant. As long as discharge continues from the peat surface at the mire margin, peat can continue to accumulate until a new equilibrium is reached between bog height and discharge level (Clymo 1984).

Influence of regional climate.-Eq. 3 shows that reduced effective moisture $(U)$ should result in a broader and flatter bog geometry, whereas with greater moisture the ratio $H_{\max } / R$ would increase, and the mire would be more convex (Ingram 1982). In fact, convexity of raised bogs in Sweden does decrease with latitude and decreasing effective moisture (Granlund 1932), and bog height and rainfall are highly correlated (Werenskjold 1943).

The effects of temperature changes are more difficult to predict because they affect $H_{\max }$ through complex interactions involving the composition of plant and microbial communities and the rates of productivity and decomposition in both catotelm and acrotelm (Clymo 1984). Damman (1986) suggests that as temperature or length of the growing season decreases, $\rho_{c}$ will decrease relative to $\alpha_{c}$, and $H_{\max }$ will consequently decrease.

\section{Application of the model}

The integrated model suggests that the geometry of ombrotrophic raised bogs will adjust to climate change regardless of the stage of bog development (i.e., vertical-growth phase or expanding-plateau phase) or direction of climatic change. Assuming that the mathematical relationships of the model are generally valid, deviations from predicted trends in development must result either from variations from the assumptions of the equations (i.e., local topographic conditions, mire coalescence) or from new hydrodynamic equilibria (imposed by regional climatic change). Here we attempt to separate those agents by comparing temporal patterns in expansion rates of several bogs within a region to identify synchronous deviations, if any. In 


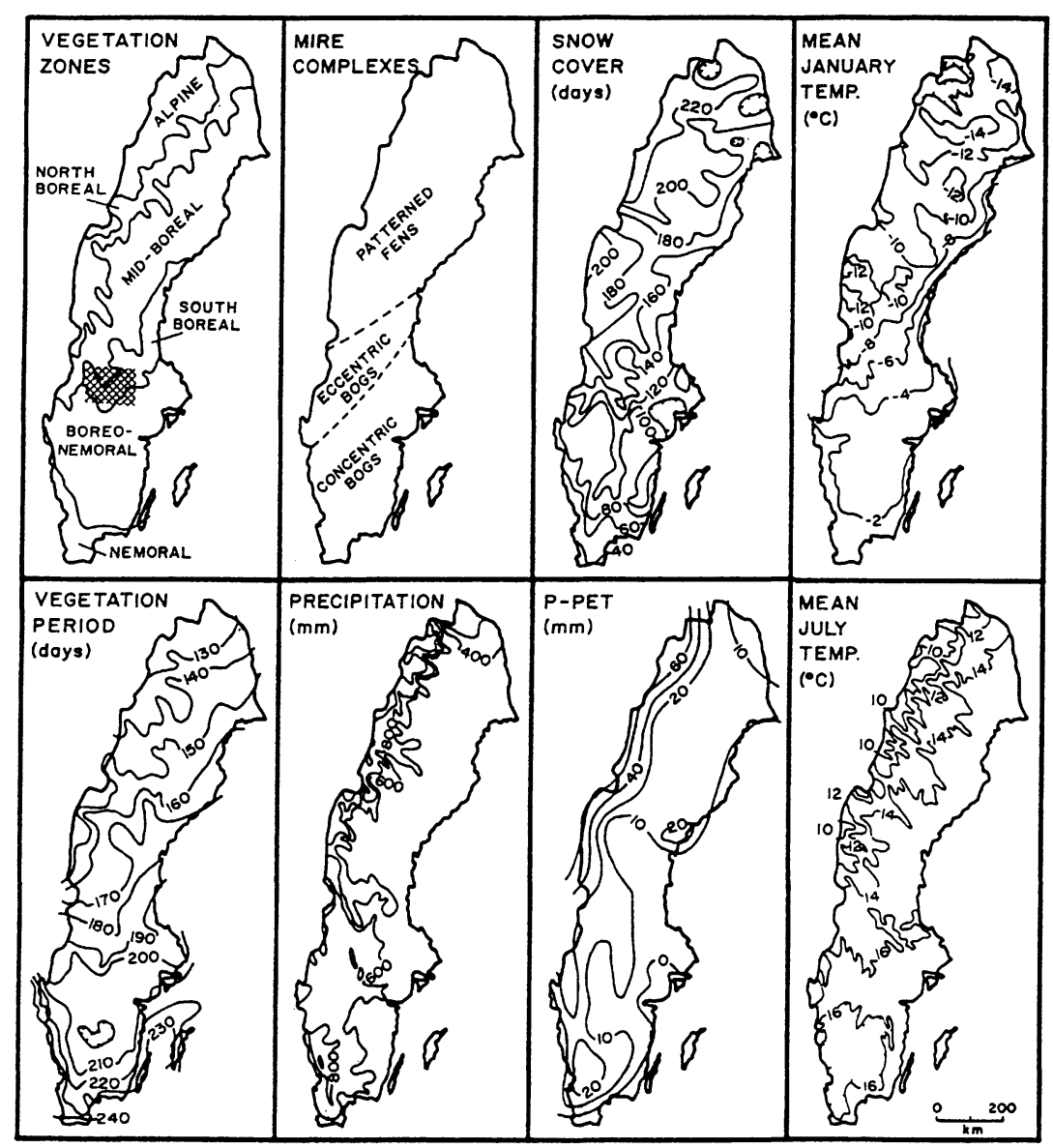

FIG. 2. Geographic distribution of vegetation zones (from Sjörs 1965), dominant mire complexes (from Sjörs 1983), and climate variables, including duration of snow cover and vegetation period, mean January and July temperatures, and mean annual precipitation and moisture balance (P-PET) in Sweden from 1931 to 1960 (from Angström 1974).

addition, we compare those trends with independent evidence of climatic change, including lake-level records that reveal variations in moisture balance.

In many cases, raised bogs overlie $\approx 20$ to $>200 \mathrm{~cm}$ of compact Carex peat, remains of fen vegetation that once occupied the site. Because fens do not conform hydrologically to the integrated model, their rates of vertical accretion and lateral expansion are not expected to follow those predicted for raised bogs.

Thus far few studies have adequately separated bog and fen development, perhaps because, in many cases, that transition is indistinct. As a result, age/depth curves from peat cores usually include both bog and fen peat (Aaby and Tauber 1974, Korhola 1992, Warner et al. 1993); "basal" radiocarbon dates refer to basal fen peat, rather than to the base of the bog peat (e.g., Foster et al. 1988, Foster and Wright 1990, Korhola 1992). Thus, temporal and spatial reconstructions of "bog" initiation and lateral expansion actually depict fen development, which does not adhere to the hydrodynamic principals of raised bogs. The extent to which the subsequent initiation and development of those raised bogs mirrored that of their underlying fens is unknown. Here we study spatial and temporal patterns in mire initiation by comparing results from seven sites in the same region. At three of those sites we compare patterns of inception and expansion of both fen and bog phases.

\section{STUdy Sites \\ Bergslagen}

The seven raised bogs under investigation are located in the Bergslagen region of central Sweden, which includes the old mining districts of southern Dalarna, northern Västmanland, and eastern Värmland (Table 1; Fig. 1). The region lies just within the south boreal vegetation zone (Sjörs 1965; Fig. 2), which is dominated by Picea abies and Pinus silvestris, with scattered occurrences of Acer platanoides, Tilia cordata, and Corylus avellana (Lindquist and Lundqvist 1962). Peatlands are common and include a variety of hydromorphological types. The Bergslagen region coincides with the transition from concentrically domed bogs toward the south to patterned fens toward the north (Fig. 2) (Sjörs 1983, Backéus 1984). 
Surficial geology in the area consists of granitic uplands covered with shallow till, and broad valleys containing coarse-grained glaciofluvial outwash plains and finer grained glaciomarine deltas (Magnusson and Granlund 1928. Lundqvist 1958). Regional climate is characterized by long winters with $>120 \mathrm{~d}$ of snow cover and $>160 \mathrm{~d}$ of frost annually. Over the period 1901 to 1930, mean January temperature was $\approx-5^{\circ} \mathrm{C}$ and mean July temperature ranged $\approx 15^{\circ} \mathrm{C}$ (Fig. 2). The annual "vegetation period" (the period over which the daily mean temperature is $>3{ }^{\circ} \mathrm{C}$ ) equaled $\approx 190 \mathrm{~d}$ : mean annual precipitation ranged between 550 and 800 $\mathrm{mm}$, and annual potential water balance (P-PET) was between 0 and $20 \mathrm{~mm}$ (Ångström 1974) (Fig. 2).

The region is characterized by climatic gradients. particularly with regard to severity of winter and length of the vegetation period, both of which vary from southeast to northwest. Summers become cooler and more humid from east to west. Those gradients are caused in part by the position of an important geologic transition from coastal lowland plains in the southeast to increasingly rugged topography toward the northwest. Decreasing moisture (P and P-PET) from west to east (Fig.2) results from the prevailing westerly winds and the rain shadow effect of the Scandinavian Mountains. Annual precipitation increases $\approx 100 \mathrm{~mm}$ for every $100 \mathrm{~m}$ elevation (Sjörs 1948), and the longitudinal gradient in mean annual precipitation within our study area is $\approx 200 \mathrm{~mm}$ over the $150 \mathrm{~km}$ east-west (Sveriges Meteorologiska och Hydrologiska Institut 1990).

Paleoenvironmental reconstructions show that the regional climate has changed considerably through the Holocene. The region was deglaciated $\approx 9600 \mathrm{yr} \mathrm{BP}$ (Lundyvist 1986). The Preboreal pioneer vegetation. which was dominated by light-demanding shrubs and herbs. was replaced by Boreal Pinus forest $\approx 9100 \mathrm{yr}$ BP. A mixed-hardwood forest occupied the region after 8200 BP: it was successively dominated by Ulmus. Tilia, and Quercus after $\approx 7800.6200$. and $3800 \mathrm{yr} \mathrm{BP}$. respectively (Almquist-Jacobson 1994). The deciduous forest was replaced by Picea-dominated forest $\approx 2200$ ) yr BP. Paleohydrologic studies on two lakes in Bergslagen demonstrate that the region was relatively moist during the early Holocene. becoming significantly drier $\approx 7000-6000$ yr BP (Almquist-Jacobson 1994. 1995). Relative moisture began increasing again by $\approx 5000 \mathrm{yr}$ $B P$, and the area became significantly wetter after $\approx 1000 \mathrm{yr}$ BP. The late Holocene trend toward increasing moisture was interrupted by temporary regressions $\approx 4000$ and $2000 \mathrm{yr}$ BP.

\section{Raised bogs}

Criteria for mire selection were chosen to simplify comparisons of field data with idealized models of raised-bog development. Most of the studied mires lie on relatively flat substrates (e.g., glaciofluvial outwash plains) that present little geomorphological obstruction to lateral expansion. All are raised bogs comprising
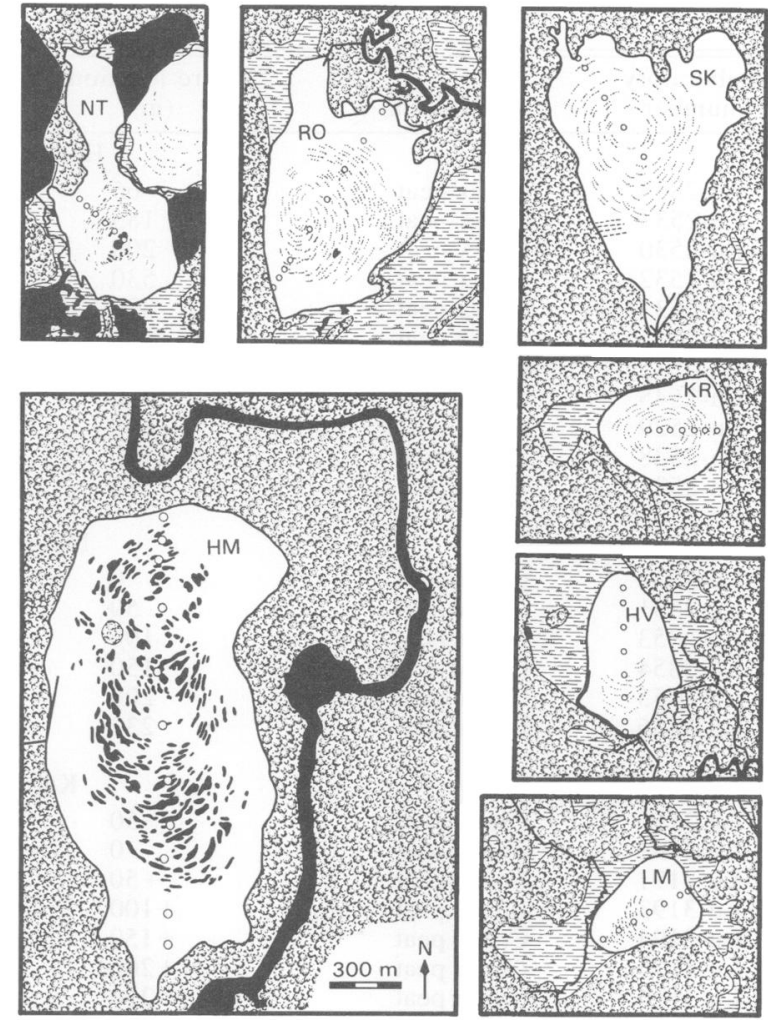

Fici. 3. Plan view of the seven mires studied: Hammarmossen (HM). Nittenmossen (NT). Kärrmossen (KR). Stora Kroksmossen (SK), Norra Römyren (RO), Limbergsmossen (IM). and Havsjömossen (HV). Open circles denote approximate locations of radiocarbon-dated cores. Scale applies to all.

several metres of almost pure Sphagnum peat overlying several decimetres of compact. highly humified Carex peat, which presumably represents minerotrophic fen. All mires were initiated through paludification rather than terrestrialization. In most cases the Carex peat is underlain by a thin layer of highly decomposed organic matter at the mineral surface.

Hammarmossen is an exceptionally large raised bog for this region. covering $\approx 150$ ha (Fig. 3 ). In plan view it is an irregular ellipse, with a striking eccentric pattern of hummocks and pools. The sandplain beneath the bog slopes gently $(0.2 \%)$ from north to south: the bog margins are adjacent to abandoned early postglacial drainage channels on the northern and eastern sides, as well as to a more recently excavated drainage ditch along the western edge. Those features probably now impede bog expansion.

Nittenmossen covers $\approx 28$ ha and has a concentric pattern of hummocks and pools, including one large pool at the center. The lightly forested bog margin is relatively steep. The mire lies on a sandplain and is bordered on the east and south by shallow lakes (Fig. $3)$.

Kärmossen covers 15 ha and is slightly elliptical 
TABLE 2. Conventional radiocarbon ages of the basal peats. Depths given are from the peat surface.

\begin{tabular}{|c|c|c|c|c|c|}
\hline $\begin{array}{l}\text { Laboratory } \\
\text { number }\end{array}$ & Material & $\begin{array}{l}\text { Core location } \\
(\mathrm{m})\end{array}$ & $\begin{array}{l}\text { Depth } \\
(\mathrm{cm})\end{array}$ & $\begin{array}{l}{ }^{14} \mathrm{C} \text { age } \\
(\mathrm{yr} \mathrm{BP})\end{array}$ & $\delta^{13} \mathrm{C}$ \\
\hline \multicolumn{6}{|c|}{ Hammarmossen } \\
\hline Lu-2833 & Carex peat & 65 & $95-100$ & $940 \pm 50$ & -25.0 \\
\hline Lu-2533 & Carex peat & 185 & $170-180$ & $2130 \pm 50$ & -25.0 \\
\hline Lu-2530 & Carex peat & 200 & $310-320$ & $3950 \pm 60$ & -25.0 \\
\hline Lu-2532 & Carex peat & 530 & $365-375$ & $5240 \pm 60$ & -25.0 \\
\hline Lu-2531 & Carex peat & 870 & $375-385$ & $5190 \pm 60$ & -25.0 \\
\hline Lu-2534 & Carex peat & 1160 & $385-395$ & $5820 \pm 60$ & -25.0 \\
\hline Lu-2535 & Carex peat & 1470 & $300-309$ & $4950 \pm 60$ & -25.0 \\
\hline Lu-2545 & Carex peat & 1660 & $310-315$ & $4130 \pm 60$ & -25.0 \\
\hline Lu-2529 & Carex peat & 1840 & $300-305$ & $3140 \pm 50$ & -25.0 \\
\hline Lu-2528 & Carex peat & 2130 & $215-220$ & $2320 \pm 50$ & -25.0 \\
\hline Lu-2527 & Carex peat & 2315 & $105-110$ & $920 \pm 45$ & -25.0 \\
\hline \multicolumn{6}{|c|}{ Nittenmossen } \\
\hline Lu-2852 & Carex peat & 0 & $328-335$ & $4910 \pm 60$ & -25.0 \\
\hline Lu-2851 & Carex peat & 50 & $340-347$ & $6070 \pm 70$ & -25.0 \\
\hline Lu-2853 & Carex peat & 100 & $293-300$ & $5450 \pm 60$ & -25.0 \\
\hline Lu-2854 & Carex peat & 150 & $237-244$ & $4290 \pm 60$ & -25.0 \\
\hline Lu-2855 & Carex peat & 200 & $118-125$ & $2290 \pm 50$ & -25.0 \\
\hline Lu-2856 & Carex peat & 233 & $23-30$ & $520 \pm 50$ & -25.0 \\
\hline \multicolumn{6}{|c|}{ Kärrmossen } \\
\hline Lu-3190 & Carex peat & -50 & 244-249 & $3410 \pm 60$ & -28.1 \\
\hline Lu-3192 & Carex peat & 0 & $237-242$ & $2910 \pm 60$ & -27.6 \\
\hline Lu-3191 & Carex peat & +50 & $241-246$ & $3230 \pm 60$ & -26.4 \\
\hline Lu-3193 & Carex peat & +100 & $233-238$ & $3440 \pm 60$ & -28.0 \\
\hline Lu-3194 & Carex peat & +150 & $232-237$ & $3290 \pm 60$ & -27.8 \\
\hline Lu-3195 & Carex peat & +200 & $225-230$ & $3530 \pm 60$ & -27.8 \\
\hline Lu-3196 & Carex peat & +250 & $120-125$ & $3470 \pm 60$ & -28.1 \\
\hline \multicolumn{6}{|c|}{ Havsjömossen } \\
\hline Lu-3181 & Carex peat & 60 & $149-154$ & $2000 \pm 50$ & -28.4 \\
\hline Lu-3180 & Carex peat & 160 & $194-199$ & $2140 \pm 50$ & -27.8 \\
\hline Lu-3179 & Carex peat & 260 & $258-263$ & $3580 \pm 60$ & -29.0 \\
\hline Lu-3177 & Carex peat & 360 & 289-294 & $5160 \pm 60$ & -29.2 \\
\hline Lu-3176 & Carex peat & 460 & $305-310$ & $5860 \pm 70$ & -28.9 \\
\hline Lu-3178 & Carex peat & 560 & $271.5-276.5$ & $5550 \pm 60$ & -28.8 \\
\hline Lu-3182 & Carex peat & 610 & $29-34$ & $1600 \pm 50$ & -27.8 \\
\hline \multicolumn{6}{|c|}{ Norra Römyren } \\
\hline Lu-3213 & Carex peat & SW400 & $255-260$ & $4460 \pm 60$ & -27.4 \\
\hline Lu-3214 & Carex peat & SW350 & 314-319 & $5700 \pm 60$ & -27.4 \\
\hline Lu-3216 & Carex peat & SW300 & $332-337$ & $6590 \pm 90$ & -27.7 \\
\hline Lu-3218 & Carex peat & SW 150 & $325-330$ & $6530 \pm 80$ & -27.8 \\
\hline Lu-3220 & Carex peat & 0 & $350-355$ & $5900 \pm 80$ & -27.9 \\
\hline Lu-3221 & Carex peat & NE150 & $368-373$ & $7320 \pm 90$ & -28.7 \\
\hline Lu-3223 & Carex peat & NE300 & $309-314$ & $7680 \pm 100$ & -28.5 \\
\hline Lu-3226 & Carex peat & NE450 & $185-190$ & $5020 \pm 80$ & -28.0 \\
\hline Lu-3227 & Carex peat & NE500 & $84-89$ & $3090 \pm 70$ & -27.5 \\
\hline Lu-3280 & Sphagnum peat & SW400 & $219-224$ & $3490 \pm 70$ & -26.4 \\
\hline Lu-3279 & Sphagnum peat & SW350 & $291-296$ & $4790 \pm 80$ & -26.2 \\
\hline Lu-3215 & Sphagnum peat & SW300 & $298-303$ & $4830 \pm 80$ & -26.1 \\
\hline Lu-3217 & Sphagnum peat & SW150 & $267-272$ & $3940 \pm 80$ & -26.2 \\
\hline Lu-3219 & Sphagnum peat & 0 & $276-281$ & $3710 \pm 70$ & -25.4 \\
\hline Lu-3222 & Sphagnum peat & NE150 & $313-318$ & $4880 \pm 80$ & -26.0 \\
\hline Lu-3224 & Sphagnum peat & NE300 & $216-226$ & $2410 \pm 110$ & -26.9 \\
\hline Lu-3225 & Sphagnum peat & NE450 & $151-156$ & $2100 \pm 60$ & -26.5 \\
\hline Lu-3281 & Sphagnum peat & NE500 & $69-74$ & $1730 \pm 60$ & -26.3 \\
\hline \multicolumn{6}{|c|}{ Limbergsmossen } \\
\hline Lu-3334 & Carex peat & +300 & $302-307$ & $8400 \pm 130$ & -26.8 \\
\hline Lu-3335 & Carex peat & +225 & $443-448$ & $8610 \pm 100$ & -26.6 \\
\hline Lu-3336 & Carex peat & +150 & $459-464$ & $8410 \pm 100$ & -26.4 \\
\hline Lu-3337 & Carex peat & +75 & 489-494 & $8240 \pm 100$ & -26.6 \\
\hline Lu-3338 & Carex peat & 0 & $498-503$ & $8180 \pm 100$ & -26.6 \\
\hline $\mathrm{Lu}-3339$ & Carex peat & -75 & $505-510$ & $8390 \pm 100$ & -26.8 \\
\hline $\mathrm{Lu}-3340$ & Carex peat & -150 & $331-336$ & $7140 \pm 90$ & -27.1 \\
\hline Lu-3341 & Carex peat & -200 & $110-115$ & $3960 \pm 70$ & -27.4 \\
\hline
\end{tabular}


TABLE 2. Continued.

\begin{tabular}{|c|c|c|c|c|c|}
\hline $\begin{array}{l}\text { Laboratory } \\
\text { number }\end{array}$ & Material & $\begin{array}{c}\text { Core location } \\
(\mathrm{m})\end{array}$ & $\begin{array}{l}\text { Depth } \\
(\mathrm{cm})\end{array}$ & $\begin{array}{l}{ }^{14} \mathrm{C} \text { age } \\
(\mathrm{yr} \mathrm{BP})\end{array}$ & $\delta^{13} \mathrm{C}$ \\
\hline Lu-3410 & Sphagnum peat & +300 & $72-77$ & $2440 \pm 70$ & -26.6 \\
\hline Lu-3411 & Sphagnum peat & +225 & $251-256$ & $2910 \pm 100$ & -26.1 \\
\hline $\mathrm{Lu}-3412$ & Sphagnum peat & +150 & $249-254$ & $3500 \pm 80$ & -26.1 \\
\hline Lu-3413 & Sphagnum peat & +75 & $305-310$ & $3580 \pm 90$ & -25.6 \\
\hline Lu-3414 & Sphagnum peat & 0 & $343-348$ & $4050 \pm 70$ & -26.0 \\
\hline Lu-3415 & Sphagnum peat & -75 & $331-336$ & $3980 \pm 90$ & -26.5 \\
\hline $\mathrm{Lu}-3416$ & Sphagnum peat & -150 & $250-255$ & $3670 \pm 70$ & -26.7 \\
\hline Lu-3417 & Sphagnum peat & -200 & $71-76$ & $2070 \pm 60$ & -26.9 \\
\hline \multicolumn{6}{|c|}{ Stora Kroksmossen } \\
\hline Lu-3441 & Carex peat & +300 & $162-167$ & $1830 \pm 80$ & -27.5 \\
\hline Lu-3444 & Carex peat & +250 & $377-382$ & $4310 \pm 90$ & -29.5 \\
\hline Lu-3445 & Carex peat & +150 & $665-671$ & $7340 \pm 90$ & -27.9 \\
\hline $\mathrm{Lu}-3448$ & Carex peat & 0 & $710-715$ & $7570 \pm 90$ & -29.8 \\
\hline $\mathrm{Lu}-3449$ & Carex peat & -150 & $678-683$ & $7380 \pm 90$ & -29.1 \\
\hline $\mathrm{Lu}-3442$ & Sphagnum peat & +300 & $120-125$ & $880 \pm 60$ & -27.5 \\
\hline $\mathrm{Lu}-3443$ & Sphagnum peat & +250 & $254-259$ & $2280 \pm 80$ & -29.5 \\
\hline Lu-3446 & Sphagnum peat & +150 & $499-504$ & $4170 \pm 80$ & -27.9 \\
\hline Lu-3447 & Sphagnum peat & 0 & $402-407$ & $2870 \pm 90$ & -26.2 \\
\hline Lu-3450 & Sphagnum peat & -150 & $482-487$ & $3520 \pm 100$ & -29.1 \\
\hline
\end{tabular}

with a regularly concentric pattern of hummocks and hollows, but no pools (Fig. 3). The bog lies on a portion of a sandplain that is bounded on the north and west by the river Klarälven. A drainage ditch excavated along the northern edge of the bog currently may constrain expansion in that direction. The bog has nearly reached topographic barriers (small ridges) toward the east and southwest.

Norra Römyren lies $25 \mathrm{~km}$ downstream from Nittenmossen on the river Nittälven. The 45-ha mire is slightly eccentric, with a diffuse pattern of hummocks and hollows radiating from the west-central portion toward the north and east (Fig. 3). The one pool is $\approx 600 \mathrm{~m}^{2}$ in area. The mire is bounded on the west by a low ridge, and on the east by a discontinuous esker. A circuitous drainage ditch carries water away from the bog's northern edge.

Havsjömossen lies $1 \mathrm{~km}$ northeast of Norra Römyren on the north side of Nittälven. There the sandplain slopes slightly toward the south, and the mire extends eccentrically southward and is bell shaped in plan view (Fig. 3). The bog covers $\approx 20$ ha. Drainage ditches have been excavated along the western, southwestern, and part of the eastern margins.

Limbergsmossen is slightly eccentric in plan view (Fig. 3), with an arching pattern of hummocks and hollows expanding toward the southwest. The 18-ha bog grades into a similar-sized fen, which is dissected by a small stream that drains toward the south. The mire is underlain by clay that probably dates to lateglacial time.

Stora Kroksmossen is triangular in plan view and covers $\approx 50$ ha (Fig. 3 ). A concentric pattern of hummocks and hollows encircles the north-central portion of the bog. There the mire is underlain by a thin layer of lake sediment and several metres of varved clay. Stora Kroksmossen is bounded on its western, northern, and eastern sides by glacial drift, and peat has been excavated from the southernmost portion of the mire during this century. A small channel drains water away from the south end.

\section{Methods}

\section{Surveying and coring}

Five mires were sampled in 1989. At each mire, a surveyor's level was used to determine surface elevations at regular intervals along a transect from the highest point or "hydrotopographic center" of the bog to the edge; at some mires the transect traversed the entire bog. (In perfectly concentric bogs, the hydrotopographic center coincides with the geographic center; this is not true for slightly eccentric bogs.) Peat depths were also determined at regular intervals along the transects. The depth of the transition from Sphagnum peat to Carex-dominated peat was noted, and samples of the basal Carex peat were collected with a Russian corer $5 \mathrm{~cm}$ in diameter (Belokopytov and Beresnevich 1955, Jowsey 1966). In three of the bogs the base of the Sphagnum peat was collected as well. Peat samples were wrapped in plastic for transport, and were prepared for radiocarbon dating within several days of collection.

Hammarmossen and Nittenmossen were sampled in 1987, and the results are reported elsewhere (Foster et al. 1988, Foster and Wright 1990). At those sites substrate elevations were not determined, and only basal Carex peat was collected.

\section{Radiocarbon dating}

Samples of basal peat $(5-10 \mathrm{~cm}$ vertical core segments) were examined for younger rhizomes that may have penetrated the older peat, dried for $48 \mathrm{~h}$ at $100^{\circ} \mathrm{C}$, and submitted to the Radiocarbon Dating Laboratory 

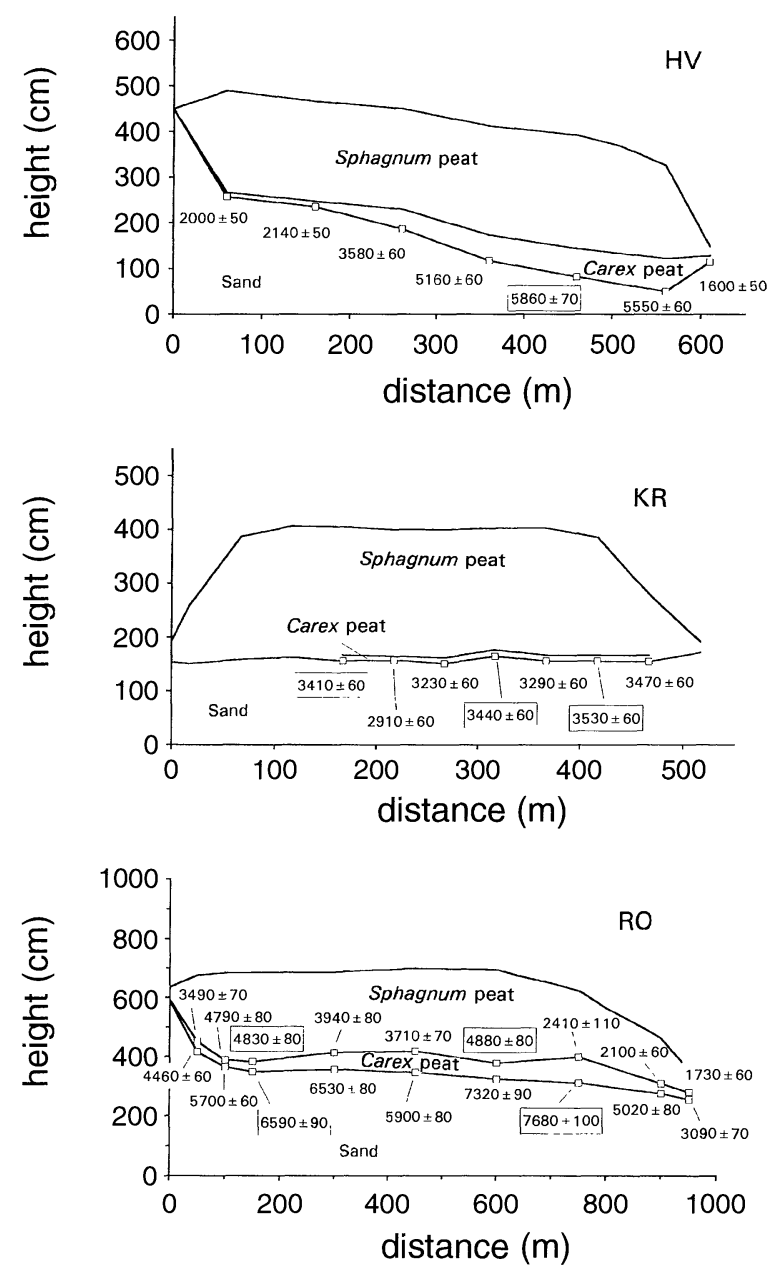

at Lund University, Sweden. All samples were pretreated with $\mathrm{HCl}$ to remove carbonates. Some samples were also treated with $\mathrm{NaOH}$. Age calculations were based on a half-life for ${ }^{14} \mathrm{C}$ of $5568 \mathrm{yr}$. The contemporary standard value used for the calculations is equal to $95 \%$ of the activity of the NBS (National Bureau of Standards) oxalic acid standard. The concentration of ${ }^{13} \mathrm{C}$ was determined for each sample, and corrections for deviations from the "normal" ${ }^{13} \mathrm{C} /{ }^{12} \mathrm{C}$ ratio for terrestrial plants were applied. Errors are quoted as \pm 1 SD and include standard deviations of count rates for the unknown sample, contemporary standard, and background.

\section{Calculations}

The rates of lateral expansion of both Carex fen and Sphagnum (i.e., raised) bog were calculated for each pair of adjacent sampling points along the transects. Those calculations were based on calendar years. The bidecadal atmospheric/inferred atmospheric calibration curve (Stuiver and Reimer 1993) was used to calibrate the radiocarbon dates. The average calendar-year age for each interval was likewise determined. The slope
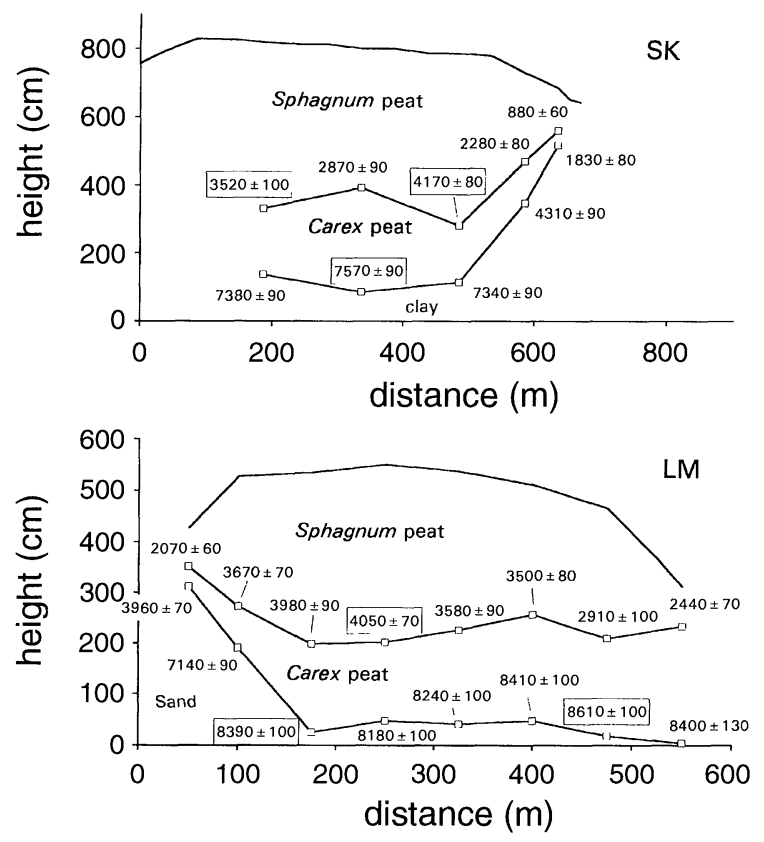

FIG. 4. Cross-sectional diagrams and radiocarbon results of the five mires surveyed: Kärrmossen (KR), Stora Kroksmossen (SK), Norra Römyren (RO), Limbergsmossen (LM), and Havsjömossen (HV), including radiocarbon dates. All sections are shown at the same vertical exaggeration. Open squares denote radiocarbon-dated samples. Boxed dates denote initiation loci.

of the substrate over which the Carex fen expanded (relative to the direction of expansion) was also calculated for each interval. That analysis was not made for the Sphagnum bog because the slope of the substrate over which the bog expanded (the Carex peat) changed through time as the fen surrounding the enlarging bog continued to accumulate peat. Potential compaction of the Carex peat would also complicate that calculation.

\section{RESUlTS AND DiscusSiON}

\section{Fen and bog initiation}

Fen initiation in Bergslagen appears to be primarily a function of local soil or hydrotopographic conditions. The oldest basal dates of Carex peat (Table 2) suggest that the fens originated between 8600 and 3500 yr BP under a broad range of regional moisture conditions (Almquist-Jacobson 1994, 1995). Fen initiation under dry climate conditions likely involved a reduction in the permeability of the underlying soil, perhaps as a result of incorporation of fine particulates through increased decomposition or addition of charcoal. Reduced infiltration, rather than increased groundwater 
discharge, could account for moist surface conditions during times when water levels in neighboring kettle lakes were low (Almquist-Jacobson 1994, 1995). Historically, some authors have attributed mire initiation to human activities on the landscape (Moore 1973). However, cultural land use, in the form of seasonal pasturing of animals, did not begin in the Bergslagen region until between $\approx 5000$ and $4000 \mathrm{yr} \mathrm{BP}$ (AlmquistJacobson 1994).

Variation in timing of fen initiation among sites within one drainage system also indicates that initiation depends largely on local site conditions. Norra Römyren and Havsjömossen, which lie $\approx 1 \mathrm{~km}$ apart on the same sandplain, began at 7700 and $5900 \mathrm{yr}$ BP, respectively, while Nittenmossen, which is located along the same river but farther upstream, began $\approx 6100$ yr BP.

Our data imply that conversion of fen to bog was facilitated by relatively dry conditions. At all of our sites, the boundary between the moderately decomposed Sphagnum peat and the underlying, highly decomposed Carex peat was sharp, suggesting either a rather abrupt transition, or even a brief (few hundred year) hiatus. Limbergsmossen, Stora Kroksmossen, and Norra Römyren began accumulating Sphagnum peat $\approx 4000,4200$, and $4900 \mathrm{yr} \mathrm{BP}$, respectively. Although $4900 \mathrm{yr}$ BP marks the end of the mid-Holocene dry period in the region, the late-Holocene increase in moisture included a marked regression between $\approx 4400$ and 3800 yr BP (Almquist-Jacobson 1994, 1995).

At a local scale conversion of fen to bog likely resulted from a decrease in nutrient-rich slope-wash reaching the site, which reduces microbial activity and decomposition rates, increases peat accumulation, and gradually leads to hydrologic isolation of the mire surface from groundwater (Heinselman 1970). Hydrologic isolation may of course occur autogenically as a consequence of increasing distance from the uplands to the

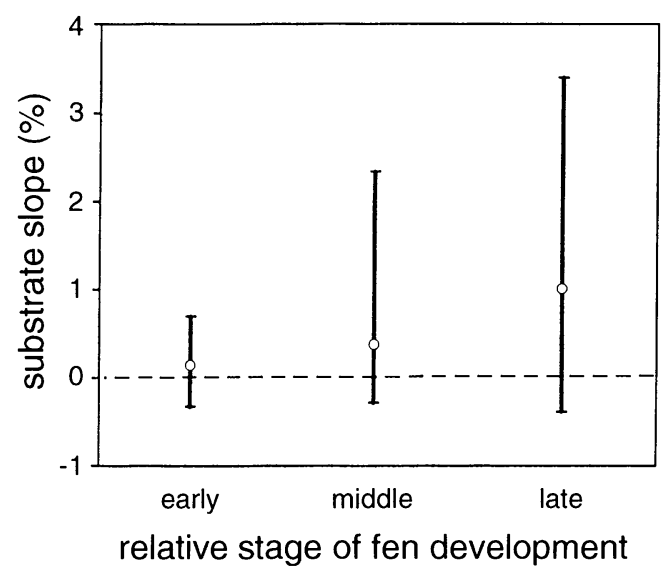

FIG. 5. Mean and range of substrate slopes encountered by the expanding fens relative to their stage of development. Early, middle, and late developmental stages are derived from dividing fen age by three.

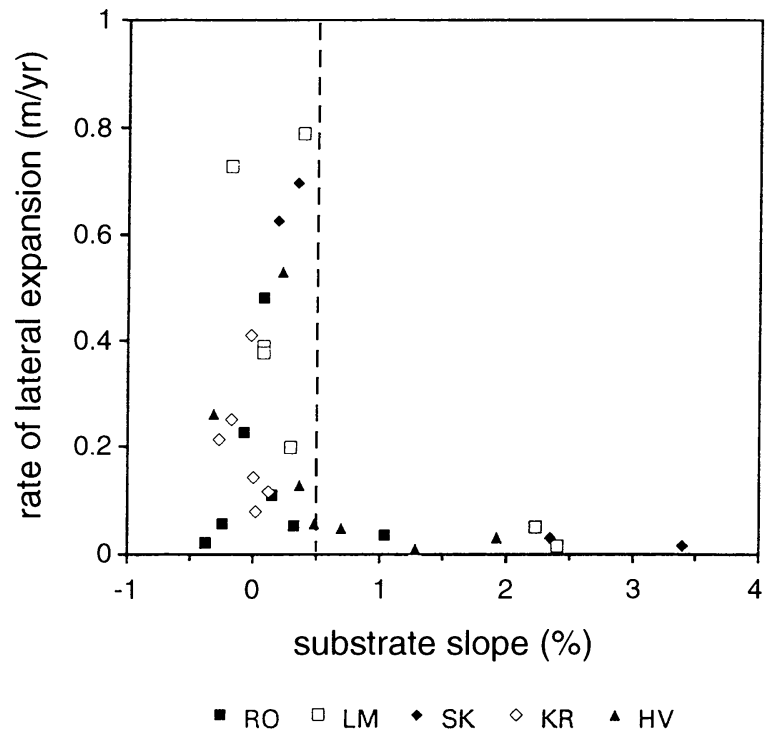

FIG. 6. Rates of lateral expansion of fens in relation to substrate slope. Kärrmossen (KR), Stora Kroksmossen (SK), Norra Römyren (RO), Limbergsmossen (LM), and Havsjömossen (HV).

mire center (resulting from the fen's expansion) or of decreasing hydrologic gradient from the upland slope to the mire center (resulting from peat accumulation). However, no consistent relationships exist among these variables for the mires in our sample, although mires forming at the base of steeper slopes (Stora Kroksmossen and Limbergsmossen, Fig. 4) do have thicker accumulations (up to $3 \mathrm{~m}$ ) of Carex peat than do those lying on flatter substrates (Kärrmossen, Hammarmossen, and Nittenmossen).

\section{Spatial patterns in fen and bog initiation}

At individual sites, both fen and bog initiation occur in a variety of spatial patterns that are presumably controlled by local soil conditions. Initiation of the fen phase of Kärrmossen and Limbergsmossen was nearly instantaneous over much of the mires' extent, while Norra Römyren began at two or more discrete loci and subsequently coalesced to form a single peatland (Fig. 4). Havsjömossen and Stora Kroksmossen apparently started from single loci, although other loci may have been missed by the sample transects. Basal dates from multiple transects at Hammarmossen and Nittenmossen (Foster et al. 1988) demonstrate that those mires spread from single loci.

Norra Römyren and Stora Kroksmossen contained evidence of Sphagnum colonization from at least two loci, while only one locus for bog initiation was found at Limbergsmossen. In only one instance were the oldest Sphagnum peat and oldest Carex peat found at the same station along the transect.

Apparently fens can originate not only from single 

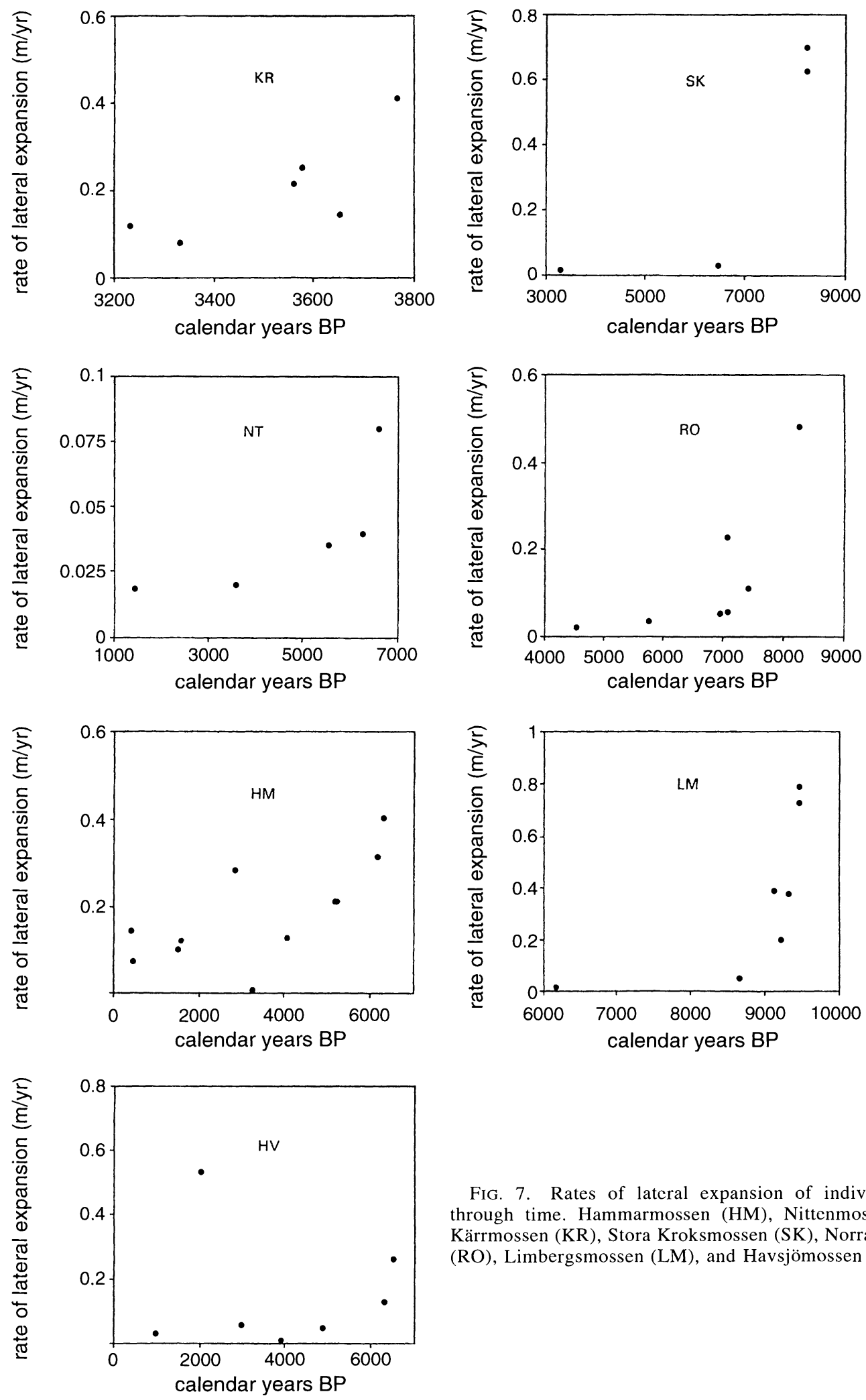

FIG. 7. Rates of lateral expansion of individual fens through time. Hammarmossen (HM), Nittenmossen (NT), Kärrmossen (KR), Stora Kroksmossen (SK), Norra Römyren (RO), Limbergsmossen (LM), and Havsjömossen (HV). 
loci, as demonstrated by Foster and Wright (1990), but also from multiple loci and even simultaneously over large areas within a few centuries, as suggested by Granlund (1932). Similar results were obtained for the fen phase of mire development in southern Finland (Korhola 1992). Accumulation of almost pure Sphagnum peat, which we assume represents initiation of the bog phase, can also occur at one or more loci. However, we have no evidence for bogs initiating simultaneously across an entire plain as described in some theoretical models (Winston 1994). As mentioned above, the relationship between bog height and radius will not conform to Eq. 1 upon coalescence of individual bogs, because the radius of the newly formed composite bog would have increased abruptly relative to its height. More field evidence is needed to determine for how long after coalescence a bog would remain in hydrologic disequilibrium. In any case, the number and location of initiation loci cannot be detected from the modern surface of a mire, and spatial patterns of fen initiation and subsequent conversion to bog appear unrelated.

\section{Topographic and climatic effects in bog and fen expansion}

At a local scale, expansion rates of both fens and bogs are determined largely by site topography. Fens tend to form in relatively flat places, thereafter expanding outward over increasingly varied topography (Fig. 5). Substrate slope appears to influence both the occurrence and the rate of expansion of fens. In our sample, few intervals between sampling points had slopes greater than $\pm 0.5 \%$ and those that did were also among the slowest to expand (Fig. 6). Slopes $>0.4$ or $0.5 \%$ probably allow excessive drainage. Similarly, de-

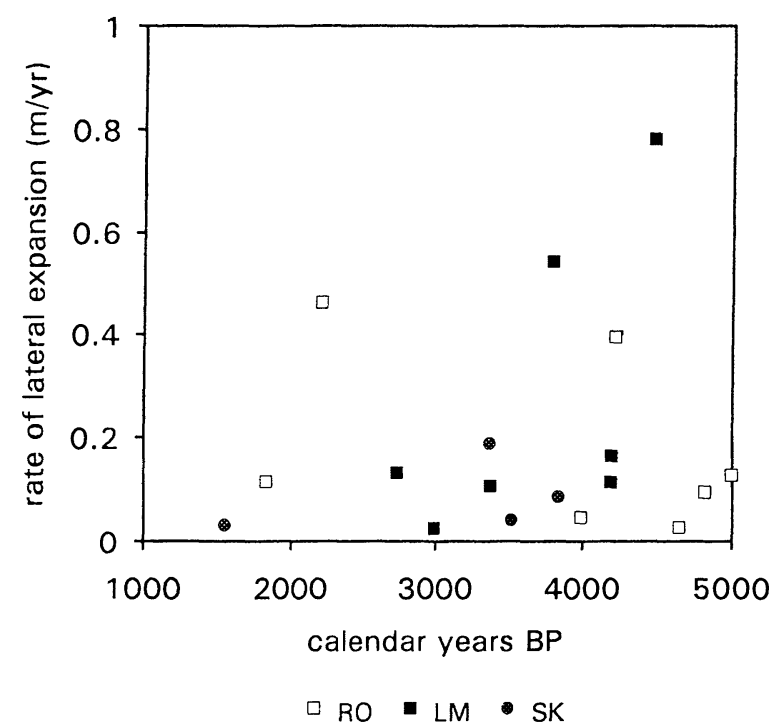

FIG. 8. Rates of lateral expansion of bogs through time. Stora Kroksmossen (SK), Norra Römyren (RO), and Limbergsmossen (LM).

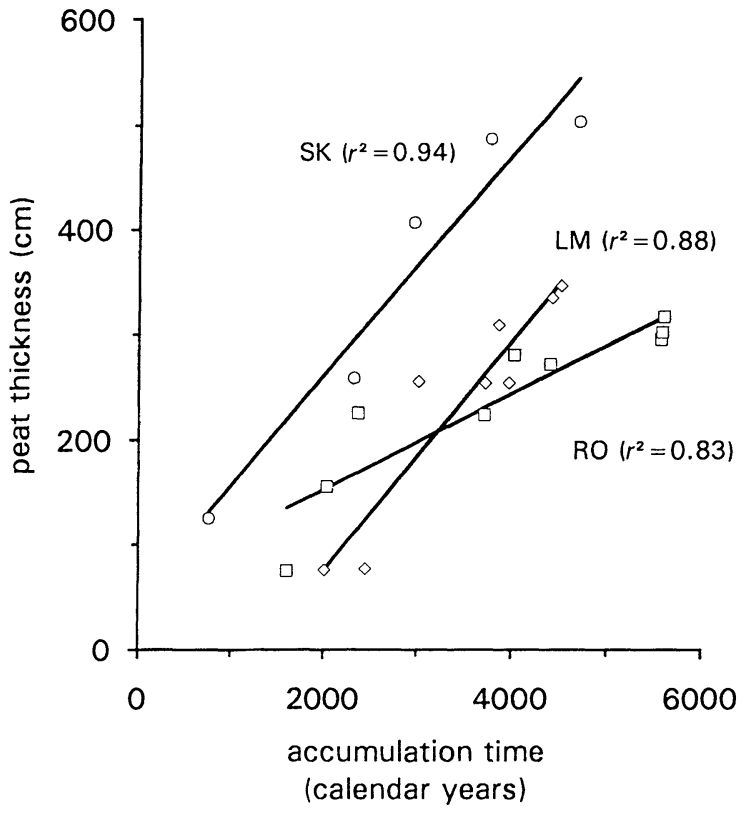

FIG. 9. Relationship between age and thickness of Sphagnum peat at each sampling point in Stora Kroksmossen (SK), Norra Römyren (RO), and Limbergsmossen (LM).

creases in rate of lateral expansion of individual fens through time (Fig. 7) likely result from changes in the topography encountered by the advancing mire margin (Heinselman 1963, Korhola 1992).

Bog expansion occurred at Norra Römyren, Limbergsmossen, and Stora Kroksmossen from $\approx 5000 \mathrm{yr}$ $\mathrm{BP}$ to at least $2000 \mathrm{yr} \mathrm{BP}$, and variations in expansion rates within individual sites are not synchronous among the three mires (Fig. 8). There is no convincing evidence of decreasing expansion rates, which would be expected for bogs approaching $H_{\max }$. Those results suggest that the expansion of these bogs has been influenced by local variations in substrate conditions, but not yet by autogenic constraints. Furthermore, the linear relationships between accumulation time and thickness of the Sphagnum peat at our sampling points within each bog (Fig. 9) are highly significant, further suggesting that the bogs have not yet reached $H_{\max }$.

Climatic effects are revealed through examination of mean collective rates of mire expansion throughout Bergslagen. In order to de-emphasize local hydrotopographic effects (Fig. 7), points having a slope $>0.5 \%$ (Fig. 6) were excluded from the calculation of mean collective rates of fen expansion for each 1000-yr interval (Fig. 10). That analysis reveals a significantly higher rate of fen expansion during the period 9000 $7000 \mathrm{yr}$ BP than during the mid-Holocene, although the rate appears to have been gradually increasing from 7000 to $2000 \mathrm{yr} \mathrm{BP}$, and was again reduced thereafter.

The slowing of fen expansion between 7500 and 6500 yr BP was likely caused by increased summer temperatures and decreased effective moisture; at the 


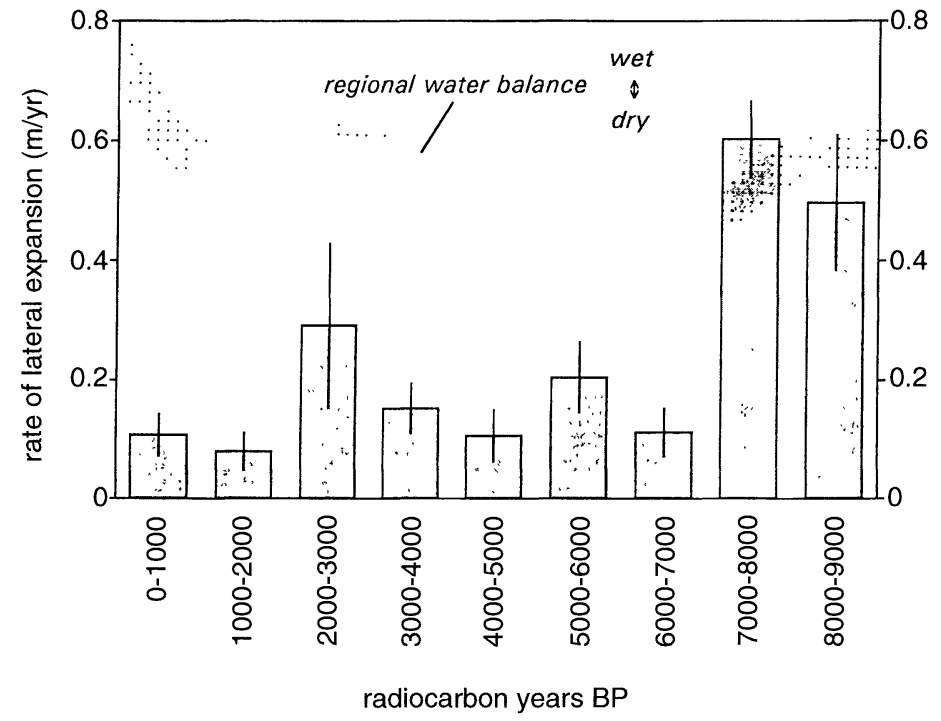

Fig. 10. Mean collective rates of lateral expansion of fens during 1000 -yr intervals. Error bars show \pm 1 SE. Curve denotes relative regional water balance (from AlmquistJacobson 1994). same time, regional lake levels dropped significantly and Pinus became dominant on sandy sites (AlmquistJacobson 1994, 1995). However, regional conditions generally became moister through the mid-Holocene, when the rate of fen expansion increased (Fig. 10). By 2000 yr BP forests of Picea and Pinus had replaced those of deciduous hardwoods as summer and winter temperatures declined; the region became slightly drier until the "Little Ice Age." The apparent slowing of fen expansion since $2000 \mathrm{yr}$ BP, during a period of cooler conditions, likely results from the fact that the only mires representing that period are Nittenmossen and Hammarmossen, which appear to have at that point reached constraints imposed by local topographic features, including the abandoned late-glacial drainage channels, upland areas, and adjoining lake basins. During the past few millennia fen expansion also has

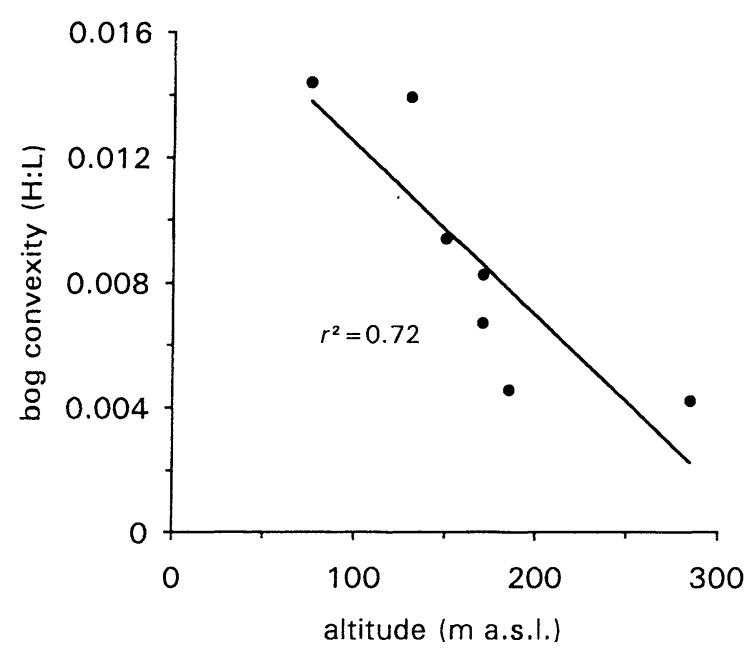

FIG. 11. Bog convexity (H:L) in relation to altitude (a.s.l. $=$ above sea level). slowed in southern Finland, as mires there have reached topographic barriers (Tolonen 1983, Korhola 1992).

Mean collective rates of lateral expansion of the raised bogs have not slowed significantly from their inception until at least $2000 \mathrm{yr}$ BP (the time span of our data), although the region has certainly become moister during that period. This suggests that moisture was not a limiting factor for growth of raised bogs in Bergslagen.

In addition, those bogs were not significantly affected by decreasing summer temperatures or shortening of the growing season that has occurred during the mid- to late Holocene (COHMAP 1988, Huntley and Prentice 1988). Theoretically, lower summer temperatures and a shorter growing season may limit bog growth by differentially affecting production and decomposition; the period over which productivity could occur would be significantly reduced relative to the period over which decomposition would occur (Flanagan and Bunnell 1976, Clymo 1983, Damman 1986). In any case, up until at least 2000 yr BP, temperature does not appear to have been a primary limiting factor. Climate has of course continued to change since 2000 yr BP. The effects of climate on the development of raised bogs during the most recent millennia can be explored through examining modern geographic trends in bog geometry.

\section{Geographic trends in bog geometry}

The modern geographic distribution and geometry of raised bogs within Bergslagen help reveal how topographic and climatic conditions together affect raised-bog development. Bergslagen coincides with the northern distributional limit of raised bogs (Fig. 2). That geographic distribution in part reflects topography and the availability of appropriate sites. Concentric raised bogs develop on flat substrates, and in the Bergs- 
lagen region those sites are limited to a few outwash plains occurring along major rivers. Elsewhere within the highly broken topography, peat deposits probably receive significant amounts of nutrient-rich water from the marginal slopes.

In addition, the altitudinal gradient from southeast to northwest accentuates the climate gradient of the region; conditions are moister and cooler toward the northwest. Both temperature and moisture can affect bog geometry, and the predominance of one factor over another likely varies throughout the range of raised bogs. If moisture balance were the dominant factor in Bergslagen we would expect a trend of increasing bog convexity toward the northwest, while, if temperature were more important, the opposite trend would occur. If climate were irrelevant, there should be no significant relationship between bog geometry and altitude. Our results (Fig. 11) are consistent with Damman's (1977, $1979,1986)$ assertion that, today, length of the growing season (temperature), rather than moisture, limits peat accumulation in raised bogs at the northern extent of their distribution.

\section{Conclusions}

By combining independent evidence for climatic change and an understanding of hydrologic controls on raised-bog development, this study provides new insights into how mire ecosystems in the Bergslagen region have responded to changes in climate. Although some spatial and temporal trends do follow changes in either temperature or moisture conditions, not all aspects of mire development appear to be closely related to climate.

The initiation of fens throughout the Holocene under a broad range of climatic conditions suggests that local factors have played the primary role in mire establishment. However, both site topography and regional water balance also affected the rate of fen expansion. Drainage at fen margins where slopes were $>0.5 \%$ inhibited rates of fen expansion at individual sites. Decreased regional water balance $\approx 7000$ yr BP inhibited fen expansion throughout Bergslagen, while topographic barriers now inhibit fen expansion at individual sites. Overall, our results suggest that fens in this region are sequestering carbon at lower rates today than they did during the early and mid-Holocene.

Bog initiation occurred during relatively dry periods, when both summer temperatures and length of the growing season were declining. Unlike the fens, the bogs appear to have continued to expand at relatively constant rates with local variations, and to have been, at least until recently, fairly insulated from climatic influences. Modern geographic trends in bog convexity in Bergslagen suggest that temperature conditions have become increasingly marginal for bog growth since $2000 \mathrm{yr} \mathrm{BP}$, and that the modern distributional limit for raised bogs in central Sweden may, in fact, be a relatively recent development.

\section{ACKNOWLEDGMENTS}

We gratefully acknowledge Nils Malmer, who has been a keen promoter of research on the raised bogs of Bergslagen, and who contributed financial support during the initial stages of this project. Hugo Sjörs spent time in the field with us and shared his valuable insights. We sincerely thank Herb Wright for assisting with the fieldwork, Jim Almendinger, Bent Aaby, Les Cwynar, and an anonymous reviewer for their valuable critiques of earlier drafts of this manuscript, and Herb Wright and George Jacobson for help with editing. Research support was provided by the National Science Foundation (BSR8906386).

\section{Literature Cited}

Aaby, B., and H. Tauber. 1974. Rates of peat formation in relation to degree of humification and local environment, as shown by studies of a raised bog in Denmark. Boreas 4:1-17.

Almquist-Jacobson, H. 1994. Interaction of Holocene climate, water balance, vegetation, fire, and cultural land-use in the Swedish Borderland. Lundqua Thesis 30, Department of Quaternary Geology, Lund University, Lund, Sweden.

. 1995. Lake-level fluctuations at Ljustjärnen, central Sweden, and their implications for the Holocene climate of Scandinavia. Palaeogeography, Palaeoclimatology, Palaeoecology, in press.

Ångström, A. 1974. Sveriges klimat. Generalstabens Litografiska Anstalts Förlag, Stockholm, Sweden.

Backéus, I. 1984. Myrar I Örebro län. Svensk Botaniska Tidskrift 78:21-44.

Barber, K. E. 1981. Peat stratigraphy and climate change. Balkema, Rotterdam, The Netherlands.

Belokopytov, I. E., and V. V. Beresnevich. 1955. Giktorf's peat borers. Torf. Prom. 8:9-10.

Blytt, A. G. 1876. Essays on the immigration of the Norwegian flora during alternating rainy and dry periods. A Cammermeyer, Christiania, Norway.

Clymo, R. S. 1978. A model of peat bog growth. Pages $187-$ 223 in O. W. Heal and D. F. Perkins, editors. Production ecology of British moors and montane grasslands. SpringerVerlag, Berlin, Germany.

- 1983. Peat. Pages 159-224 in A. J. P. Gore, editor. Ecosystems of the world. 4a. Mires: swamp, bog, fen and moor: general studies. Elsevier, New York, New York, USA.

- 1984. The limits to peat bog growth. Philosophical Transactions of the Royal Society, London B 303:605-654. COHMAP (Cooperative Holocene Mapping Project). 1988. Climatic change of the last 18,000 years: observations and model simulations. Science 241:1043-1052.

Damman, A. W. H. 1977. Geographical changes in the vegetation pattern of raised bogs in the Bay of Fundy region of Maine and New Brunswick. Vegetatio 35:137-151.

-1979. Geographic patterns in peatland development in eastern North America. Pages 42-57 in E. Kivinen, L. Heikurainen, and P. Pakarinen, editors. Classification of peat and peatlands. Proceedings of the International Peat Society Symposium. International Peat Society, Hyytiälä, Finland.

- 1986. Hydrology, development, and biogeochemistry of ombrogenous peat bogs with special reference to nutrient relocation in a western Newfoundland bog. Canadian Journal of Botany 64:384-394.

Digerfeldt, G. 1986. Studies on past lake-level fluctuations. Pages 127-144 in B. E. Berglund, editor. Handbook of Holocene palaeoecology and palaeohydrology. John Wiley \& Sons, New York, New York, USA.

Eurola, S., and K.-D. Vorren. 1980. Mire zones and sections in North Fennoscandia. Aquilo Ser. Botanica 17:39-56.

Flanagan, P. W., and F. L. Bunnell. 1976. Decomposition 
models based on climatic variables, microbial respiration, and production. Pages 437-457 in J. M. Anderson and A. Macfadyan, editors. The role of terrestrial and aquatic organisms in decomposition processes. Blackwell, Oxford, England.

Foster, D. R., and H. E. Wright, Jr. 1990. Role of ecosystem development and climate change in bog formation in central Sweden. Ecology 71:450-463.

Foster, D. R., H. E. Wright, Jr., M. Thelaus, and G. A. King. 1988. Bog development and landform dynamics in central Sweden and south-eastern Labrador, Canada. Journal of Ecology 76:1164-1185.

Frenzel, B. 1983. Mire-repositories of climatic information or self-perpetuating ecosystems? Pages 35-65 in A. J. P. Gore, editor. Ecosystems of the world. 4a. Mires: swamp, bog, fen and moor: general studies. Elsevier, New York, New York, USA.

Glaser, P. H., and J. A. Janssens. 1986. Raised bogs in eastern North America: transitions in landforms and gross stratigraphy. Canadian Journal of Botany 64:395-415.

Godwin, H. 1952. Recurrence-surfaces. Danmarks Geologiske Undersögelse, II Raekke 80:22-30.

Granlund, E. 1932. De svenska högmossarnas geologi. Sveriges Geologiska Undersökning, serie C, 373.

Heinselman, M. L. 1963. Forest sites, bog processes and peatland types in the glacial Lake Agassiz region, Minnesota. Ecological Monographs 33:327-374.

. 1970. Landscape evolution, peatland types, and the environment in the Lake Agassiz Peatlands Natural Area, Minnesota. Ecological Monographs 40:235-261.

Huntley, B., and I. C. Prentice. 1988. July temperatures in Europe from pollen data, 6000 years before present. Science 241:687-690.

Ingram, H. A. P. 1982. Size and shape in raised mire ecosystems: a geophysical model. Nature 27:300-303.

Ivanov, K. E. 1981. Water movement in mirelands. Academic Press, London, England.

Jowsey, P. C. 1966. An improved peat sampler. New Phytologist 65:245-248.

Korhola, A. 1992. Mire induction, ecosystem dynamics and lateral extension on raised bogs in the southern coastal area of Finland. Fennia 170:25-94.

Lindquist, B., and M. Lundqvist. 1962. Vegetationsregioner. Atlas över Sverige, Svenska Sällskapet for Antropologi och Geographi, Stockholm, Sweden.
Lundqvist, J. 1958. Studies of the Quaternary history and deposits of Värmland, Sweden. Sveriges Geologiska Undersökning, serie C, 559 .

- 1986. Late Weichselian glaciation and deglaciation in Scandinavia. In V. Sibrava, D. Q. Bowen, and G. M. Richmond, editors. Quaternary glaciation in the Northern Hemisphere. Quaternary Science Reviews 5:269-292.

Magnusson, N. H., and E. Granlund. 1928. Beskrivning till Kartbladet Filipstad. Sveriges Geologiska Undersökning, serie Aa, 165.

Malmer, N. 1992. Peat accumulation and the global carbon cycle. In M. Boer and E. Koster, editors. Greenhouse-impact on cold-climate ecosystems and landscapes. Catena 22:97-110.

Moore, P. D. 1973. The influence of prehistoric cultures upon the initiation and spread of blanket bog in upland Wales. Nature 241:350-353.

Sjörs, H. 1948. Myrvegetation i Bergslagen. Acta Phytogeographica Suecica 21. Almqvist and Wiksells, Uppsala, Sweden.

Sjörs, H. 1965. Features of land and climate. The plant cover of Sweden, Acta Phytogeographica Suecica 50. Almqvist and Wiksells, Uppsala, Sweden.

-1983. Mires of Sweden. Pages 69-94 in A. J. P. Gore, editor. Ecosystems of the world. 4b. Mires: swamp, bog, fen and moor; regional studies. Elsevier, New York, New York, USA.

Stuiver, M., and P. J. Reimer. 1993. Radiocarbon calibration program rev 3.0.3c. Radiocarbon 35:215-230.

Sveriges Meteorologiska och Hydrologiska Institut. 1990. Data rörande Sveriges nederbördsklimat, normalvärden för perioden 1951-1980. SMHI, Norrköping, Sweden.

Tolonen, K. 1983. Turpeiden luokitus ja stratigrafia. Pages 29-32 in J. Laine, editor. Suomen suot ja niiden käyttö. Suoseura ry, IPS:n Suomen kansallinen komitea. Helsinki, Finland.

Warner, B. G., R. S. Clymo, and K. Tolonen. 1993. Implications of peat accumulation at Point Escuminac, New Brunswick. Quaternary Research 39:245-248.

Werenskjold, W. 1943. Högmossarnas välvning i Södra Sverige. Geologiska Föreningen Stockholm Förhandlingar 65: 304-305.

Winston, R. B. 1994. Models of the geomorphology, hydrology, and development of domed peat bodies. Geological Society of America Bulletin 106:1594-1604. 